\title{
PENERAPAN MEDIA FILM SEBAGAI SUMBER BELAJAR UNTUK MENINGKATKAN KEMAMPUAN MENGOLAH INFORMASI SISWA DALAM PEMBELAJARAN SEJARAH
}

\author{
Lusiana Surya Widiani, Wawan Darmawan, Tarunasena Ma'mur \\ Universitas Pendidikan Indonesia
}

\begin{abstract}
The background of this study is the lack of ability to process information of students in history subject in grade 11 Social I Pasundan 8 Senior High School Bandung. This can be seen from most students were only able to develop the ability to remember and memorize. When students are exposed to an issue, students were not able to process the information. The ability to process the information outlined in this study is the student's ability to process information from a variety of sources of information when learning takes place. To that end, researchers are trying to do research with the goal of improving students' ability to process information through the implementation offilm media in history subject. This research is using a classroom action research methods design of Kemmis and Mc. Taggart. The classroom action research method (PTK) were done with four steps: planning, action, observation, and reflection. Based on the research that has been done, student progress in achieving the criteria on the indicator of the ability to process information that has been determined to experience a significant increase in each cycle. Through the implementation of film as media, the students used to process the information they receive. This shows that in the application of the film to enhance the students' ability to process information is one way that can be used in the teaching of history in schools. The results of this study can be used as advice or recommendations as well as consideration for teachers so that students will have the ability to process information so that the teaching process become more meaningful.
\end{abstract}

Keywords: Film, Students Ability to Process Information
ABSTRAK
Latar belakang dari penelitian ini adalah masih rendahnya kemampuan mengolah informasi siswa dalam pembelajaran sejarah di kelas XI IPS I SMA Pasundan 8 Bandung. Hal ini terlihat dari banyaknya siswa yang hanya mampu mengembangkan kemampuan mengingat dan mengafal. Retika dihadapkan pada suatu persoalan, siswa belum mampu dalam mengolah informasi. Kemampuan mengolah informasi yang ditekankan pada penelitian ini adalah kemampuan siswa dalam mengolah informasi dari berbagai sumber informasi saat pembelajaran berlangsung. Untuk itu, peneliti mencoba melakukan penelitian dengan tujuan meningkatkan kemampuan mengolah informasi siswa melalui penerapan media film dalam pembelajaran sejarah. Adapun metode penelitian yang digunakan adalah metode penelitian tindakan kelas dengan menggunakan desain penelitian dari Kemmis dan Mc. Taggart. Metode penelitian tindakan kelas (PTK) dilakukan dengan empat tahap yaitu perencanaan (plan), tindakan (act), pengamatan (observing), dan refleksi (reflecting). Berdasarkan penelitian yang telah dilakukan, perkembangan siswa dalam mencapai kriteria pada indikator kemampuan mengolah informasi yang telah ditentukan mengalami peningkatan yang cukup signifikan pada setiap siklusnya. Melalui penerapan media film siswa terbiasa untuk mengolah informasi yang mereka peroleh. Hal ini menunjukkan bahwa dalam penerapan media film untuk meningkatkan kemampuan mengolah informasi siswa merupakan salah satu cara yang dapat digunakan dalam pembelajaran sejarah di sekolah. Hasil penelitian ini dapat dijadikan saran atau rekomendasi serta bahan pertimbangan untuk guru agar siswa memiliki kemampuan mengolah informasi sehingga pembelajaran sejarah lebih bermakna.

Kata kunci: Media film, Kemampuan Mengolah Informasi Siswa.

Author correspondence

Email: lusianasuryawidiani@ymail.com

Available online at http: // http://ejournal.upi.edu/index.php/factum 


\section{PENDAHULUAN}

Pelaksanaan pendidikan di Indonesia harus sesuai dengan tujuan yang diharapkan. Tujuan pendidikan tidak selalu berpatokan pada nilai-nilai angka yang diperoleh peserta didik dalam suatu kegiatan pembelajaran. Namun, lebih pada keterampilan dan kemampuan dilihat dari aspek kognitif, afektif dan psikomotor. Pada dasarnya tujuan pembelajaran sejarah mengarahkan peserta didik untuk meningkatkan kemampuan dalam berpikir. Terdapat empat tujuan secara ideal pembelajaran sejarah yang harus dicapai menurut Ismaun (2001, hlm. 114) :

mampu memahami sejarah, dalam arti: (1) memiliki pengetahuan dan pemahaman tentang peristiwa; (2) memiliki kemampuan berpikir secara kritis yang dapat digunakan untuk menguji dan memanfaatkan pengetahuan sejarah; (3) memiliki keterampilan sejarah yang dapat digunakan untuk mengkaji berbagai informasi yang sampai kepadanya guna menentukan kesahihan informasi tersebut; dan (4) memahami dan mengkaji setiap perubahan yang terjadi dalam masyarakat di lingkungan sekitarnya serta digunakan dalam mengembangkan kemampuan berpikir kritis dan analitis.

Mata pelajaran sejarah merupakan bagian dari ilmu pengetahuan sosial yang membahas mengenai perubahan aspek cerita kehidupan manusia di masa lampau yang lebih banyak mengingat hafalan tokoh atau nama pahlawan, tanggal, tahun dan tempat terjadinya peristiwa. Materi sejarah yang berisikan fakta-fakta, konsep-konsep harus mampu melatih daya nalar peserta didik dalam mengembangkan kemampuan berpikir. Dalam proses pembelajaran sejarah bagi peserta didik dengan menggunakan ranah kognitif menjadi sangat sulit, karena pada ranah ini perlu adanya suatu pengolahan informasi yang diserap pada setiap materi pembelajaran. Hal ini diperkuat oleh Beyer (Hasan, 1996, hlm. 222)'kemampuan pengolahan informasi dianggap sebagai proses berpikir'.

Berdasarkan hasil observasi yang telah dilakukan di kelas XI IPS 1 SMA Pasundan 8 Bandung, peneliti menemukan bahwa terdapat beberapa permasalahan yang terjadi saat proses pembelajaran sejarah berlangsung. Pertama, pembelajaran selama ini disampaikan kepada peserta didik lebih kepada penyampaian satu arah, artinya siswa hanya memperoleh informasi dari guru saja, sehingga dalam pembelajaran seperti ini peserta didik kurang dilibatkan dalam menemukan informasi yang mereka peroleh. Kedua, berdasarkan hasil wawancara dengan beberapa peserta didik pada dasarnya peserta didik lebih tertarik melihat film atau video. Ketiga, kemampuan peserta didik dalam menghubungkan informasi yang satu dengan informasi yang lainnya masih terlihat rendah. Hal ini terbukti peserta didik hanya mampu mengembangkan kemampuan mengingat dan menghafal saja, dilihat dari hasil tes yang diberikan kurang menekankan pada peserta didik untuk mengolah informasi, memecahkan masalah ataupun pemahaman dari materi pembelajaran sejarah.

Dari penjelasan di atas dapat disimpulkan bahwa peserta didik tidak mampu menangkap pokok-pokok materi di awal pembelajaran, peserta didik lebih menekankan kepada fakta-fakta informasi yang diungkapkan oleh guru tanpa mampu menganalisis serta mengolah informasi 
yang telah di dapat. Tinggi rendahnya kemampuan peserta didik dalam merekam informasi sangat ditentukan oleh kemampuan otak atau kemampuan berpikir dalam mengolah informasi. Dalam Rohim (2009, hlm. 59) menjelaskan bahwa "proses pengolahan informasi, yang juga disebut komunikasi interpersonal meliputi sensasi, persepsi, memori dan berpikir". Untuk mengembangkan kemampuan mengolah informasi Hasan (1996, hlm. 222) menambahkan bahwa dalam kegiatan mengolah informasi merupakan bagian dari kemampuan menganalisis.

Kemampuan analisis di sini peserta didik dapat menentukan keterhubungan antara satu sumber informasi dengan informasi lainnya. Mengolah informasi yang di dapat, sehingga peserta didik tidak dapat begitu saja menerima informasi yang mereka dapat dari berbagai sumber, menentukan pokok-pokok pikiran yang mendasari suatu informasi dan menarik konsekuensi dari informasi baik dalam waktu maupun dalam dimensi. Kemampuan mengolah informasi merupakan perpaduan dari proses berpikir peserta didik, karena ketika peserta didik mengolah informasi, peserta didik harus bisa mengembangkan kemampuannya secara bertahap. Menurut pendapat Anwar (2006, hlm. 29) kemampuan berpikir meliputi "kemampuan menggali informasi, kemampuan mengolah informasi, kemampuan mengambil keputusan dan memecahkan secara kreatif". Dengan berpikir, peserta didik akan terlatih untuk menyelesesaikan masalah sesuai dengan nalar atau logika.

Pada dasarnya kegiatan mengolah informasi terdapat pada Kurikulum 2006 maupun Kurikulum2013. Dalamkurikulum
2013 mengolah informasi lebih ditujukan kepada kajian saintifik, namun sebenarnya terdapat kesamaan pada kurikulum 2006 dengan kurikulum 2013 misalnya dalam pendekatan ilmiah yang pada hakekatnya adalah pembelajaran berpusat pada siswa, siswa mencari pengetahuan bukan menerima pengetahuan. Dalam KTSP kegiatan mengolah informasi terdapat pada kegiatan proses pembelajaran yang mencakup, eksplorasi, elaborasi dan konfirmasi, salah satu proses yang menggunakan kemampuan berpikir anak terdapat pada kegiatan elaborasi. Kegiatan elaborasi ini memberikan kesempatan peserta didik untuk berpikir, menganalisis, menyelesaikan masalah, dan bertindak tanpa rasa takut.

Berdasarkan permasalahan tersebut, maka perlu dikembangkan dengan penerapansebuahmediapembelajaranyang harapkan dapat membantu siswa dalam meningkatkan kemampuan mengolah informasi siswa. Media pembelajaran saat ini mengalami perkembangan yang sangat pesat. Hal ini dapat dikatakan bahwa media pembelajaran adalah alat yang dapat membantu dalam proses pembelajaran, tidak hanya itu saja media pembelajaran dianggap sebagai salah satu sumber belajar yang ikut membantu guru dalam memperkaya wawasan peserta didik serta berfungsi untuk memperjelas makna pesan yang ini disampaikan. Sependapat dengan Trianton (2013, hlm. xi) menyatakan bahwa "media yang baik adalah yang mengandung pesan sebagai perangsang sehingga dapat menumbuhkan motivasi belajar pada siswa (peserta didik). Tujuannya adalah agar peserta didik menjadi tidak bosan atau cepat jenuh dalam mengikuti proses belajar". 
Menurut pendapat Gagne dan Briggs (Arsyad, 2009, hlm. 81) mengatakan bahwa 'media pembelajaran meliputi alat yang secara fisik digunakan untuk menyampaikan isi materi pengajaran, yang terdiri dari antara lain buku, tape rceorder, kaset, video, camera, video recorder, film slide (gambar bingkai), foto, gambar, grafik, televisi dan komputer'. Salah satu ciri media pembelajaran adalah bahwa media mengandung dan membawa pesan atau informasi kepada penerima yaitu siswa.

Berbagai jenis media pembelajaran yang ada saat ini, peneliti memutuskan untuk memilih media film sebagai media pembelajaran. Pengertian film itu sendiri menurut Munadi (2008, hlm. 116) "film adalah alat komunikasi yang sangat membantuprosespembelajaranefektif.Apa yang terpandang oleh mata dan terdengar oleh telinga, lebih cepat dan lebih mudah diingat dari pada apa yang hanya dapat dibaca atau hanya didengar". Sementara Trianton (2013, hlm 57) menyatakan media film adalah "alat penghubung yang berupa film; media massa alat komunikasi seperti radio, televisi, surat kabar, majalah yang memberikan penerangan kepada orang banyak (massa) dan mempengaruhi pikiran mereka". Penggunaan media film sebagai media belajar atau sumber belajar, dapat membantu pendidik dan peserta didik menjalin komunikasi dan interaksi yang lebih hidup, sehingga pesan pembelajaran yang ingin disampaikan dapat tercapai dengan lebih baik dan sempurna.

Melalui Penggunaan film diharapkan siswa mampu mengolah informasi yang ada dari isi film tersebut dengan begitu siswa dapat menganalisis serta dapat mengelompokkan data atau informasi mana saja yang sesuai dengan fakta dan realita nya tidak hanya itu saja siswa dapat mengembangkan proses berpikirnya, maka dari itu penggunaan media film dapat menjelaskan suatu proses dan menjelaskan suatu keterampilan dan semua siswa dapat belajar dari film tersebut sekaligus dapat mengembangkan kemampuan mengolah informasi siswa.

Selain itu, terdapat beberapa kegiatan yang dapat meningkatkan kemampuan mengolah informasi siswa. Kegiatankegiatan tersebut dapat ditemukan di dalam langkah-langkah penerapan media film. Guru menayangkan film di dalam kelas serta guru memberikan kesempatan kepada siswa untuk mencari sumber informasi yang ada, sehingga siswa dilatih untuk mengambil poin-poin penting yang ada dalam isi pokok film serta mampu mengolah informasi yang telah didapat. Pembelajaran menggunakan media film ini dilakukan secara berkelompok, setiap kelompok berdiskusi membahas permasalahan dari lembar kerja siswa (LKS) yang diberikan oleh guru diharapkan peserta didik terbiasa bagaimana cara mengolah sumber informasi menjadi hasil informasi yang bermakna.

Dari pemaparan di atas bahwa melalui melalui pemutaran film peserta didik dilatih untuk mengambil poin-poin penting yang ada dalam isi pokok film serta mampu menganalisis dan mengolah informasi yang telah didapatkan utnuk menciptakan informasi yang lebih akurat dengan membandingkan dengan sumber informasi lainnya. Dihubungkan dengan kemampuan mengolah informasi, film dapat dijadikan sebagai sumber informasi yang dapat dijadikan sebagai pembanding 
antara sumber informasi lainnya, baik melalui sumber buku maupun sumber internet. Maka tujuan dari proses penelitian ini yaitu untuk mengembangkan kemmapuan berpikir siswa sebab kemampuan mengolah informasi termasuk kegiatan mengelompokkan dan menganalisis, dengan begitu siswa tidak mudah percaya begitu saja terhadap setiap informasi yang mereka dapat.

Pada penelitian ini yang menjadi pokok permasalahan yang dikaji adalah "Bagaimana upaya meningkatkan kemampuan mengolah informasi siswa melalui penggunaan media film dalam proses pembelajaran sejarah di kelas XI IPS I Pasundan 8 Bandung”.

\section{METODE PENELITIAN}

Metode penelitian yang digunakan untuk mendapatkan data penelitian yaitu dengan menggunakan metode penelitian tindakan kelas (PTK). Menurut Daryanto (2011, hlm. 4) menyatakan "Penelitian Tindakan Kelas adalah penelitian yang dilakukan oleh guru di dalam kelasnya sendiri melalui refleksi diri dengan tujuan untuk memperbaiki kualitas proses pembelajaran di kelas, sehingga hasil belajar siswa dapat ditingkatkan". Sedangkan desain penelitian yang digunakan yaitu model spiral dari Kemmis \& Mc.Taggart. dimana dalam desainnya ini terdapat empat komponen penting yang saling berhubungan yang terdiri dari komponen perencanaan (planning), tindakan (acting), pengamatan (observing) dan refleksi (reflecting).

Sekolah yang dijadikan sebagai tempat penelitian adalah SMA Pasundan 8 Bandung, SMA Pasundan 8 Bandung terletak di Jl. Cihampelas No. 167.
Kecamatan Coblong Kelurahan Cipaganti Kota Bandung Jawa Barat 40131. Kelas yang dipilih sebagai subjek penelitian disesuaikan dengan karakteristik permasalahan yang diteliti sebelumnya sebagai upaya untuk memperbaiki proses pembelajaran di dalam kelas. Adapun kelas yang menjadi objek penelitian ini adalah kelas XI IPS 1 terdiri dari 33 orang siswa dengan 14 siswa perempuan dan 19 siswa laki-laki.

Adapun instrumen penelitian yang digunakan yaitu pedoman observasi, catatn lapangan, pedoman wawancara, lembar kerja sisiwa (LKS). Adapun teknik pengumpulan data yang digunakan dalam penelitian ini berupa observasi, wawancara dan studi dokumentasi. Setelah data terkumpul kegiatan yang dilakukan selanjutnya adalah mengolah data tersebut. Pengolahan data dilakukan setelah pengumpulan data dengan menggunakan berbagai teknik pengumpulan data, data yang dilakukan bersifat kuantitatif dan kualitatif, data tersebut dapat memberikan makna yang berarti dalam memecahkan masalah dalam penelitian.

Hasil penelitian yang diperoleh oleh peneliti perlu adanya pengujian untuk menilai keabsahan atau tingkat kesahihan untuk mengetahui kebenarannya dari sebuah penelitian agar dapat dipertanggungjawabkan. "Di dalam Penelitian Tindakan Kelas (PTK), cara yang dapat dilakukan untuk pengujian validasi data dengan melakukan member chek yaitu "memeriksa kembali keteranganketerangan atau informasi data yang diperoleh selama observasiatau wawancara dari narasumber, apakah keterangan, atau informasi, atau penjelasan itu tetap sifatnya atau tidak berubah sehingga 
dapat dipastikan keajegannya, dan data itu terperiksa kebenarannya" (Wiriaatmadja, 2014, hlm 168). Kemudian melakukan Audit trail yang dapat memeriksa kesalahan-kesalaahn yang dilakukan oleh penelti. Dan yang terkahir yaitu Expert Opinion dimana hal ini dilakukan dengan pendapat dari pakar atau pembimbing.

\section{HASIL PENELITIAN DAN PEMBAHASAN}

Hasil penelitian ini diperoleh setelah melakukan pengumpulan data dari tanggal 28 Agustus 2015 sampai dengan 23 Oktober 2015 di SMA Pasundan 8 Bandung. Penelitian ini dilakukan sebanyak 4 siklus yang terdiri dari 4 kali pertemuan. Hasil penelitian ini diperoleh melalui penilaian terhadap siswa selama kegiatan proses pembelajaran berlangsung dan pemberian tugas berupa lembar kerja siswa sesuai dengan materi pembelajaran. Kegiatan pembelajaran yang dilakukan melalui penerapan media film ini dilakukan melalui kelompok yang terdiri dari 6-7 orang siswa.

Pada siklus I tindakan I tahap perencanaan di awali dengan melakukan perijinan dengan pihak sekolah dan guru untuk melakuakn penelitian, kemudian mempersiapkan rencana pelaksanaan pembelajaran (RPP). Langkah selanjutnya peneliti mempersiapkan instrumen yang akan digunakan, dan mempersiapkan alatalat yang akan dibutuhkan ketika tindakan berlangsung. Pada tahap pelaksanaan peneliti mempersiapkan materi perkembangan kerajaan Hindu-Budha di Nusantara mengenai perkembangan kerajaan Majapahit menyajikannya dalam bentuk power point, selanjutnya siswa menyimak film dengan judul "Mahkota
Majapahit”. Selanjutnya siswa ditugaskan untuk mencari informasi melalui film yang telah ditayangkan dan menghubungkan informasi yang satu dengan informasi lainnya yang relevan dengan materi pembelajaran. Pada tindakan I ini terlihat bahwa kemampuan siswa dalam mengolah informasi masih sangat rendah. Hal ini ditunjukkan dengan perolehan nilai setiap kelompok, dimana skor yang diperoleh masih jauh dari skor maksimal yang ditentukan oleh peneliti yaitu 12 . tiga kelompok yang memperoleh kategori kurang baik dengan skor 4 yaitu kelompok 3, 4 dan 5. Sementara dua kelompok yang memperoleh kategori cukup baik dengan skor 6 yaitu kelompok 1 dan 2. Berdasarkan hasil penelitian yang telah dilakukan bahwa siswa masih belum memahami cara proses menjawab permasalahan yang ada di dalam lembar kerja siswa dengan mengaitkan hasil informasi yang ada di film.

Pada sklus II tindakan II perencanaan dilakukan dengan mempersiapkan segala sesuatu yang dibutuhkan dalam kegiatan pembelajaran termasuk RPP, instrumen penelitian, Pada tahap pelaksanaan peneliti mempersiapkan materi pembelajaran mengenai "Peranan Wali Songo dalam proses penyebaran agama Islam di Nusantara”. Selanjutnya siswa menyimak penayangan film dengan judul "kisah 9 wali". Pada tindakan II ini hasil dari proses penelitian masih menjukkan belum adanya perubahan ke arah yang lebih baik. Hal ini ditunjukkan dengan perolehan nilai kelompok dimana skor yang diperoleh. Terdapat empat kelompok yang mendapatkan kategori cukup baik yaitu kelompok 1 memperoleh skor 7 , kelompok 2 memperoleh skor 6, kelompok 
3 memperoleh skor 5 dan kelompok 4 memperoleh skor 6. Sementara hanya satu kelompok yang memperoleh kategori kurang baik dengan skor 4 yaitu kelompok 5 .

Pada siklus III tindakan III perencanaan yang dilakukan hampir sama dengan tindakan sebelumnya yaitu mempersiapkan perangkat pembelajaran yang akan digunakan. Materi yang akan dipersiapkan oleh peneliti yaitu mengenai kerajaan bercorak Islam di Nusantara "Kerajaan Banten". selanjutnya peneliti mempersiapkan film berjudul "Perkembangan Islam di Wilayah Kerajaan Banten".pada tindakan III menunjukkan adanya perubahan ke arah yang lebih baik. Namun demikian, kemampuan mengolah informasi siswa dalam pembelajaran sejarah perlu ditingkatkan kembali. Hal ini di tunjukkan dengan perolehan nilai kelompok dimana skor yang diperoleh. Terdapat tiga kelompokyang mendapatkan kategori baik yaitu kelompok 1 dengan perolehan skor 9, kelompok 2 mempeorleh skor 9, kelompok 3 memperoleh skor 8 . Sementara dua kelompok mendapatkan kategori cukup baik yaitu kelompok 4 memperoleh skor 6 dan kelompok 5 memperoleh skor 6. Berdasarkan hasil penelitian bahwa masih kurangnya siswa dalam kemampuan memberikan sudut pandang mereka untuk mengolah informasi atau menganalisis terlebih dahulu hasil informasi yang mereka dapat.

Pada siklus IV tindakan IV tahap perencanaan dilakukan hampir sama dengan siklus-siklus sebelumnya yaitu mempersiapkan perangkat pembelajaran yang akan digunakan. materi yang akan dijadikan sebagai bahan penelitian yaitu mengenai "Kerajaan Mataram Islam".
Selanjutnya peneliti mempersiapkan film dokumenter yang berjudul "Islam Nusantara (kerajaan Mataram“. Pada tindakan IV menunjukkan bahwa kemampuan mengolah informasi siswa pada tindakan ini sudah baik atau siswa sudah mampu mengolah informasi yang mereka peroleh. Hal ini di tunjukkan dengan perolehan nilai skor kelompok yaitu terdapat empat kelompok yang mendapatkan kategori baik yaitu kelompok 1 memperoleh skor 11, kelompok 2 memperoleh skor 9, kelompok 3 memperoleh skor 9 dan kelompok 5 memperoleh 9. Sementara kategori yang cukup baik hanya satu kelompok yaitu kelompok 4 dengan perolehan skor 6 .

Berdasarkan hasil temuan di lapangan, yaitu selama melakukan penelitian mengenai penerapan media film sebagai sumber belajar untuk meningkatan kemampuan mengolah informasi siswa dalam pembelajaran sejarah, memperoleh hasil bahwa kemampuan mengoah informasi siswa mengalami peningkatan dalam setiap tindakan. Peningkatan tersebut dinilai dari proses diskusi kelompok dengan mendiskusikan permasalahan yang terdapat di dalam lembar kerja siswa (LKS), karena pada proses ini setiap siswa mampu menggunakan kemampuan berpikirnya untuk menganalisis serta mengolah terlebih dahulu informasi yang telah mereka peroleh. Peningkatan kemampuan mengolah informasi siswa pada saat diskusi secara berkelompok terlihat dari presentase rata-rata yang dijabarkan dalam tabel ini. 


\section{Tabel 1}

Pencapaian Skor Kemampuan Mengolah Informasi Siswa pada Saat Diskusi Kelompok dalam Mengerjakan LKS

\begin{tabular}{|c|c|c|c|c|}
\hline Kelompok & Tindakan I & Tindakan II & Tindakan III & Tindakan IV \\
\hline 1 & 6 & 7 & 9 & 11 \\
\hline 2 & 6 & 8 & 9 & 9 \\
\hline 3 & 4 & 5 & 8 & 9 \\
\hline 4 & 4 & 6 & 6 & 6 \\
\hline 5 & 4 & 4 & 6 & 9 \\
\hline Jumlah Skor & & & & \\
\hline Kelompok & 24 & 30 & 38 & 44 \\
\hline Skor Maksimal & \multicolumn{4}{|c|}{60} \\
\hline $\begin{array}{l}\text { Rata-rata } \\
\text { presentase }\end{array}$ & $40 \%$ & $50 \%$ & $63,3 \%$ & $73,3 \%$ \\
\hline Kategori Nilai & Cukup Baik & Cukup Baik & Cukup baik & Baik \\
\hline
\end{tabular}

Perhitungan rata-rata (presentase) $=$ Jumlah Perolehan kelompok x 100

$$
\text { skor maksimal }
$$

\section{Tabel 2}

Konversi Rata-rata Perolehan Skor Kemampuan Mengolah Informasi Siswa pada Saat Diskusi Kelompok dalam Mengerjakan LKS

\begin{tabular}{|l|l|}
\hline Nilai & Skor (Presentase) \\
\hline Baik & $66,7 \%-100 \%$ \\
\hline Cukup Baik & $33,4 \%-66,6 \%$ \\
\hline Kurang Baik & $1 \%-33,3 \%$ \\
\hline
\end{tabular}

Tabel di atas, menunjukkan rata-rata presentase skor keseluruhan kelompok pada tindakan ke-I yaitu 40\%, pada tindakan ke-II mengalami kenaikan menjadi 50\%. Dari tindakan I ke tindakan II mengalami peningkatan sebesar $10 \%$. Pada tindakan ke-III mengalami kenaikan 63,3\%. Dengan demikian maka tindakan II ke tindakan ke III mengalami peningkatan sebesar $13,3 \%$. Dan pada tindakan keIV mengalami kenaikan yang cukup signifikan menjadi 73,3\%, dari tindakan III ke tindakan IV mengalami peningkatan sebesar $10 \%$.
Secara umum, terdapat beberapa peningkatan yang bisa diamati melalui aktivitas siswa dalam proses pembelajaran di dalam kelas setelah diterapkannya media film yaitu: pertama, siswa mampu menghubungkan hasil informasi yang mereka peroleh dari berbagai sumber dengan materi permasalahan yang ada di dalam LKS. Kedua, siswa mampu mencari sumber informasi yang relevan sebagai solusi untuk menjawab pon-poin masalah yang diberikan oleh guru. Ketiga, siswa terbiasa mengolah hasil informasi 
yang mereka peroleh agar memperoleh hasil informasi yang sesuai dengan faktafakta sejarah. Keempat, siswa mulai mampu menyimpulkan hasil analisis atau kesimpulan dengan menggunakan kalimat sendiri.

Kenaikan presentase rata-rata kemampuan mengolah informasi siswa melalui penerapan media film mengindikasikan adanya perubahan terhadap cara berpikir siswa dalam mengolah informasi yang awalnya mereka hanya terdapat pada kategori yang rendah jadi berada pada kategori baik bahkan mencapai 73,3\%. Bahwa pada dasarnya kemampuan mengolah informasi dianggap sebagai proses berpikir seseorang. Hal ini sependapat menurut Hasan (1996, hlm. 222) yang menyatakan bahwa 'kemampuan pengolahan informasi dianggap sebagai proses berpikir'. Hal ini menunjukkan bahwa kemampuan mengolah informasi merupakan salah satu wujud bagaimana proses belajar siswa yang dilakukan di dalam kelas. Sehingga kemmapuan berpikir siswa dalam mengolah informasi mulai terlihat membuahkan hasil yang cukup signifikan.

Kemampuan mengolah informasi siswa dengan penerapan media film dalam pembelajaran sejarah memiliki keterkaitan sendiri dalam proses pembelajaran sebab dengan penampilan media film dapat dimanfaatkan sebagai media penyampai pesan informasi yang efektif. Menurut Munadi (2008, hlm. 116) "film adalah alat komunikasi yang sangat membantu proses pembelajaran yang efektif". Sependapat dengan dengan Trianton (2013, hlm. xi) menyatakan "media yang baik adalah yang mengandung pesan sebagai perangsang sehingga dapat menumbuhkan motivasi belajar pada siswa (peserta didik). Dengan demikian media film ini mendorong dan memberikan kesempatan kepada siswa untuk terampil dalam mencari informasi. Artinya, siswa didorong untuk mampu mencari serta mengolah informasi yang diperoleh serta mampu menyimpulkan hasil informasi yang mereka peroleh ke dalam tulisan sesuai dengan pemahaman mereka. Siswa juga akan mampu membangun dan menumbuhkan motivasi cara belajar mereka sehingga proses belajar mengajar dapat berjalan dengan efektif.

\section{SIMPULAN}

Secara keseluruhan, perencanaan dalam penelitian ini dapat berjalan dengan baik. Dari awal perijinan, observasi, dan menyiapkan perangkat pembelajaran yang akan digunakan untuk melaksanakan kegiatan pembelajaran dengan menggunakan penerapan media film di kelas XI IPS I. Selain itu peneliti mempersiapkan instrumen penelitian yang dapat memudahkan peneliti untuk memperoleh data. Perencaaan yang dilakukan oleh peneliti pada setiap siklusnya mengalami perkembangan ke arah yang lebih baik dan semakin matang.

Pelaksanaa penerapan media film untuk meningkatkan kemampuan mengolah informasi siswa ini secara keseluruhan dapat berjalan dengan cukup baik yang dilakukan sebanyak empat tindakan dan empat siklus. Kegiatan pelaksanaan penerapan media film tentunya disesuaikan dengan kondisi dan karakteristik kelas yang dijadikan sebagai tempat penelitian yaitu kelas XI IPS 1. Pembelajaran di awali dengan pemaparan materi dengan menyajikan power point serta menayangkan media film yang 
berkaitan dengan materi pembelajaran, kemudian dilakukan diskusi kelompok untuk memecahkan permasalahan yang telah ada di lembar kerja siswa serta mengetahui seberapa besar kemampuan siswa dalam mengolah informasi yang telah di dapat.

Berdasarkan hasil dari penelitian yang dilakukan, secara keseluruhan kemampuan mengolah informasi siswa mengalami peningkatan yang cukup signifikan setelah diterapkannya media film dalam proses pembelajaran. Melalui penerapan media film siswa terbiasa untuk mengolah informasi yang mereka peroleh dari hasil tayangan yang ditampilkan, selain itu pula siswa mampu membandingkan serta menghubungkan informasi yang mereka peroleh dari sumber buku dan internet, tidak hanya itu saja siswa dilatih untuk menarik kesimpulan. Penerapan media film mampu untuk meningkatkan kemampuan mengolah informasi siswa pada mata pelajaran sejarah. Hal ini terlihat dari hasil tindakan yang dilakukan sebanyak empat kali, di mana dalam setiap tindakan ke-I sampai pada tindakan keIV mengalami peningkatan yang cukup signifikan.

\section{DAFTRA PUSTAKA}

Anwar (2006). Pendidikan kecakapan hidup. Alfabeta: Bandung

Arsyad, A. (2009). Media pembelajaran. Jakarta: PT. Raja Grafindo Persada.

Daryanto. (2011). Penelitian tindakan kelas dan penelitian tindakan sekolah beserta contoh-contohnya. Yogyakarta: Gava Media.

Hasan. H. (1996). Pendidikan ilmu sosial. Jakarta: Departemen Pendidikan dan Kebudayaan Direktorat Jenderal Pendidikan Tinggi Proyek Pendidikan Tenaga Akademik.

Ismaun (2001). Paradigma pendidikan sejarah yang terarah dan bermakna. Jurnal Pendidikan Sejarah. 4, (II).

Munadi. Y. (2008). Media pembelajaran sebuah pendekatan baru. Jakarta: Gunung Persada Perss.

Rohim, S. (2009). Teori komunikasi perspektif, ragam, \& aplikasi. Jakarta: Rineka Cipta

Trianton. T. (2013). Film sebagai media belajar. Yogyakarta: Graha Ilmu.

Wiriaatmadja.R.(2014). Metode penelitian tindakan kelas. Bandung: PT. Remaja Rosdakarya 